\title{
Ботанические исследования
}

\author{
УДК 581.9(470.43):58.006(045)
}

\author{
Т.Е.Зенкина, В.Н. Ильина
}

\section{СОСТОЯНИЕ ЦЕНОПОПУЛЯЦИЙ НЕКОТОРЫХ РЕДКИХ ВИДОВ РАСТЕНИЙ САМАРСКОЙ ОБЛАСТИ НА ТЕРРИТОРИИ ПАМЯТНИКА ПРИРОДЫ РЕГИОНАЛЬНОГО ЗНАЧЕНИЯ «СЕРНОВОДНЫЙ ШИХАН»}

Исследовано состояние ценопопуляций четырех редких видов Artemisia salsoloides Willd., Hedysarum grandiflorum Pall., Oxytropis floribunda (Pall.) DC., Stipa korshinskyi Roshev. в петрофитных степях Высокого Заволжья (Самарская область) на основе закономерностей их пространственно-онтогенетической структуры. Обработка данных проводилась с помощью программного пакета R, позволяющего выполнять расчеты пространственной статистики. Так осуществлялась оценка стационарности, изотропности и интенсивности размещения растительных объектов. Выполнялась характеристика мозаики размещения особей всех видов, отмеченных в границах исследуемой территории. С помощью карт локальной плотности выявлено разрежение особей на окраине модельной площадки, обусловленное выпасом скота. Поведение функции Рипли показало независимое распространение видов как следствие слабой межвидовой конкуренции. Анализировался пространственный узор и возрастной спектр исследуемых редких охраняемых видов-доминантов. Отмечено отсутствие проростков и сенильных растений в связи с воздействием неблагоприятных факторов экзогенной природы. Наиболее многочисленными являлись $i m-v$ и $g_{2}$ состояния. В соответствии с поведением $K(r)$ функции выявлено случайное размещение четырех преобладающих видов, свидетельствующее об их оптимальном расположении в пределах исследуемого участка. Исследовались закономерности взаимного размещения прегенеративных и генеративных особей Artemisia salsoloides, Hedysarum grandiflorum, Oxytropis floribunda. Расчет кросс-функции Рипли показал, что особи разных возрастных групп описываемых видов располагаются независимо друг от друга, демонстрируя отсутствие внутривидовой конкуренции. Без сомнения, на пространственное размещение особей слагающих фитоценоз видов растений оказывает воздействие как осуществляемый выпас скота, так и особенности почвенного покрова участка, что проявляется в значительной элиминации растений на начальных стадиях онтогенеза. Тем не менее ценопопуляции редких видов являются устойчивыми, зрелыми и перспективными, особи распределены оптимальным образом, минимизирующим энергетические затраты.

Ключевые слова: редкий вид, Artemisia salsoloides, Hedysarum grandiflorum, Oxytropis floribunda, Stipa korshinskyi, ценопопуляция, пространственная структура, функция Рипли, Самарская область, Серноводный шихан.

DOI: $10.35634 / 2412-9518-2021-31-1-5-15$

Особенности пространственной организации растительных сообществ и составляющих их ценотических популяций растений в условиях антропогенной трансформации природных комплексов могут считаться основополагающим аспектом при изучении фитоценозов и их динамики на территории Самарской области. Данный регион имеет давнюю историю освоения и высокую интенсивность использования, что в первую очередь отразилось на степных комплексах. В настоящее время целинных степей в регионе практически не осталось, в основном они сохранились лишь на «неудобьях» с точки зрения сельскохозяйственного использования, то есть на склонах балок, оврагов, увалов и сыртов [1]. Более или менее сохранившие естественные черты участки имеют статус охраняемых природных территорий, однако общая площадь их для всей Самарской области незначительна и требует увеличения [2]. Красная книга Самарской области [3; 4] включает значительное число именно степных представителей, число местообитаний которых сокращается и в настоящее время в связи с отчуждением под строительство различных объектов. Другие же природные комплексы подвергаются активному использованию при рекреации и выпасе скота.

На территории Самарской области нами проводится изучение особенностей структуры ценопопуляций редких видов растений, в том числе их онтогенетического состава $[5 ; 6]$ и пространственного размещения особей [7].

Исследования особенностей пространственного расположения особей разных видов проведено на территории памятника природы регионального значения «Серноводный шихан» (также известен под местным названием «Серноводский шихан»). Территориально природный комплекс расположен 
в Самарском Высоком Заволжье на отрогах Бугульмино-Белебеевской возвышенности вблизи населенных пунктов пгт. Серноводск и Сургут (Сергиевский район, Самарская область), в связи с чем испытывает значительную антропогенную нагрузку (выпас скота, рекреация, пожоги степного войлока и сухого травостоя, отчуждение под грунтовые дороги, дачные участки). Кроме того, склоны шихана, занятые степной, в верхней части в большей степени петрофитной, растительностью, подвержены ветровой и водной эрозии. Несмотря на это, флора Серноводного шихана достаточно богата, и данный природный комплекс нередко приводится в качестве эталонного для северо-восточной части Самарской области.

Цель настоящей работы - оценить состояние ценопопуляций четырех редких видов Artemisia salsoloides Willd., Hedysarum grandiflorum Pall., Oxytropis floribunda (Pall.) DC., Stipa korshinsky Roshev. на территории памятника природы регионального значения «Серноводный шихан».

В качестве индикатора состояния растительного покрова предлагается использовать характер пространственно-возрастной структуры ценопопуляций (ЦП) вышеуказанных видов, в составе коржинскоковыльно-разнотравного сообщества (Herbae stepposae-Stipa korshinskyi Roshev.), находящегося под воздействием умеренного выпаса.

Для изучения пространственного узора ценопопуляций закладывалась пробная площадка размером $25 \mathrm{~m}^{2}$. На данной площади находилось также три вида содоминантов: Artemisia salsoloides, Hedysarum grandiflorum, Oxytropis floribunda.

Для установления достоверного размера пробной площадки был выполнен расчет элементарной демографической единицы (ЭДЕ) популяции для трех исследуемых видов [8;9]. Вычисления проводились с учетом времени онтогенеза, минимального и максимального радиуса репродуктивной активности, коэффициента периодичности плодоношения данных видов. Результаты расчетов показали, что значения площади ЭДЕ при минимальной и максимальной площади репродуктивной активности варьировали в следующих пределах: Artemisia salsoloides $\left(1,8-21 \mathrm{~m}^{2}\right)$, Hedysarum grandiflorum $\left(0,5-23 \mathrm{~m}^{2}\right)$, Oxytropis floribunda (0,56-16,8 м²). Следовательно, размер учетной площади не должен быть меньше ЭДЕ, представляющей собой территорию, на которой происходит полный оборот поколений исследуемых видов.

Исследования в границах описываемой территории выполнялись по трем направлениям:

1) характеристика мозаики размещения особей всех отмеченных видов;

2) анализ пространственного узора редких охраняемых видов;

3) выявление закономерностей внутривидовых отношений редких охраняемых растений.

Алгоритм использования пространственно-онтогенетической структуры в качестве диагностического признака состояния ценопопуляций детально рассматривается в работах М.Б. Фардеевой [10-12].

\section{Материалы и методы исследований}

На стационарном участке в составе изучаемого растительного сообщества отмечено 12 видов растений, среди которых 6 являются редкими. Среди них 4 представителя имели достаточную численность особей для оценки их пространственного размещения.

Artemisia salsoloides Willd. (Asteraceae) - полукустарничек до 45 см высотой с крепким деревянистым стержневым корнем. Вегетативные и плодоносящие побеги многочисленные, прямые, у основания одревесневающие, с бурой корой. Листья толстоватые, темно-зеленые, 2,5-4,5 см длиной, нижние и средние стеблевые рассечены на 3-5 линейных сегментов, верхние - цельные. Соцветия - корзинки, собранные в узкую густую кисть. Цветет в июле-августе. Опыляется ветром. Плодоносит в августе сентябре. Плод - яйцевидная семянка. Размножение семенное. В регионе является редким видом. Относится к средне- и нижневолжско-нижнедонско-восточнопричерноморско-южноуральскопредкавказским эндемикам. В Самарской области произрастает на северной границе ареала. Среди лимитирующих факторов отмечены низкая конкурентоспособность особей, зарастание степных склонов дерновинными растениями, карьерная разработка известняка, выпас, рекреационная нагрузка [3; 4].

Hedysarum grandiflorum Pall. (Fabaceae) - травянистый стержнекорневой многолетник 15-35 см высотой. Листья непарноперистые, с обеих сторон серебристо-волосистые. Листочки в числе 2-5 пар продолговатые или эллиптические. Крупные цветки собраны в густые кисти. Венчики до 2-2,5 см длиной, беловато-желтые. Цветет в мае-июне. Размножение семенное. Лимитирующие факторы: относительно узкий диапазон эколого-фитоценотических условий, патиентный тип жизненной страте- 
Состояние ценопопуляций некоторых редких видов растений Самарской области...

гии, положение на границе ареала, неконтролируемый выпас, карьерные разработки, чрезмерная рекреационная нагрузка, степные пожары [4]. Восстанавливающийся в Самарской области вид, произрастающий здесь на северной границе ареала. Включен в Красную книгу Российской Федерации (категория 3в) [13].

Oxytropis floribunda (Pall.) DC. (Fabaceae) - многолетнее травянистое растение 15-30 см высотой. Стебли многочисленные, тонкие, простые или восходящие. Все растение седое от мягких волосков. Листья на длинных черешках. Листочки 8-15-парные, овально-ланцетные или продолговатые, заостренные. Цветочные кисти рыхлые, многоцветковые, на длинных пазушных цветоносах, длиннее листьев. Венчик алый или розово-пурпуровый. Цветет в июне-июле. Размножение семенное. К лимитирующим факторам относят узкий диапазон эколого-фитоценотических условий произрастания, патиентный тип жизненной стратегии, малый банк семян в почве, положение на границе ареала, неконтролируемый выпас, карьерные разработки, эрозия склонов, чрезмерная рекреационная нагрузка, степные пожары [4]. Редкий в Самарской области вид, произрастающий на северной границе ареала.

Stipa korshinskyi Roshev. (Роасеаe) - многолетнее травянистое растение 30-60 см высотой, образующее плотные дерновины. Листья тонкие, щетиновидно сложенные, остро шероховатые. Ости 712 см длиной, дважды коленчато-согнутые, покрытые короткими волосками до 0,6 мм. Цветет в июне. Ветроопыляемое растение. Плодоносит в июле. Анемохор. Размножается семенами. В Самарской области встречается на западной границе ареала. В качестве лимитирующих факторов указаны относительно узкая экологическая амплитуда, положение на границе ареала, низкая конкурентоспособность, уплотнение почвы скотом при чрезмерной рекреационной нагрузке, уничтожение мест обитания (строительство дорог, разработка карьеров) [4]. Абсолютно заповедный режим (исключая крутые каменистые склоны) нецелесообразен, допустим умеренный выпас.

На этапе предварительных исследований нами применялись популяционно-онтогенетические методы [14-16].

Для анализа использовались методы математического моделирования пространственного размещения растительных объектов и статистической обработки данных с помощью программного пакета R. Возможности языка программирования позволяют выявить внутрипопуляционные пространственные характеристики различных онтогенетических групп, межпопуляционные взаимодействия различных видов растений, оценить значимость выявленных пространственных закономерностей [17]. Данные подходы применялись другими исследователями ранее в ходе изучения пространственно-возрастной структуры популяций видов семейства маковые (Corydalis bulbosa) [18], семейства орхидные (Cypripedium calceolus, Orchis militaris) [9; 19], дерновинных видов трав [12], семейства вересковые (Vaccinium myrtillus) [11;20], растений различных жизненных форм [10; 17].

Использование математического аппарата подробно описано в некоторых источниках при анализе горизонтальной структуры древостоев [21;22].

Проверка стационарности размещения особей выполнялась с помощью критерия согласия Пирсона $\chi^{2}$, проверка изотропности осуществлялась с помощью критерия Колмогорова-Смирнова [22; 23].

Построение карт локальной плотности выполнялось с помощью метода бегущего или скользящего окна (moving window) [24] на основе ядерной функции kernel (kernel function) [25; 26]. Интенсивность расположения исследуемых видов анализировалась с помощью ядерной функции на основе Гауссова распределения с учетом граничной коррекции [23].

Для проверки предположения о независимом размещении особей (complete spatial randomness, CSR) на описываемом участке, выполнялось тестирование гипотезы о согласии модели однородного поля Пуассона (для особей, расположенных стационарно и изотропно) и модели неоднородного поля Пуассона (для особей, расположенных нестационарно и анизотропно) [22; 23; 27].

Проверка гипотез выполнялась с помощью оценки $K(r)$ - функции Рипли. Для анализа пространственных закономерностей между расположением двух классов особей использовалась кроссфункция Рипли [28]. Оценка статистической значимости $K(r)$ функции осуществлялась с помощью имитационных процедур Монте-Карло $[12 ; 23 ; 27 ; 29]$. Так эмпирическое значение $K(r)$ функции сравнивается с теоретическим значением $K(r)=\pi r^{2}$, соответствующем CSR. Если при некотором $r$ функция выходит из границ доверительного интервала и значение $K(r)>\pi r^{2}$, это говорит о наличии агрегации на расстояниях меньших $r$. При выходе из границ доверительного интервала и при значении $K(r)<\pi r^{2}$ отмечается регулярное размещение (отталкивание) на расстояниях меньших $r$ [23]. 
Выполнялось построение карт распределения доминирующих онтогенетических состояний. Данные карты позволяют выделить фрагменты территории, где число особей в прегенеративных возрастных состояниях (pre) превышает число генеративных экземпляров (gene) (т.е. $\mathrm{p}=\mathrm{n}_{\text {pre }} / \mathrm{n}_{\text {gene }}>0,5$ ) $[26 ; 30]$.

Все вычисления производились в среде R (version 3.3.2) с помощью пакета SPATSTAT [31].

\section{Результаты и их обсуждение}

Изучение ЦП редких видов растений осуществлено в составе коржинскоковыльноразнотравного сообщества (Herbae stepposae-Stipa korshinskyi Roshev). В растительном сообществе выявлено 12 видов растений. Для петрофитного сообщества на территории Высокого Заволжья такое количество видов можно считать невысоким, но характерным для петрофитных степей. Других представителей в данном сообществе не зарегистрировано, однако в целом флора Серноводного шихана насчитывает более 450 таксонов, среди которых более 120 произрастают в различных степных фитоценозах. В составе петрофитных степных сообществ региона нередко отмечается совместное произрастание нескольких редких видов растений, зачастую являющихся доминантами изучаемого фитоценоза. В описываемом фитоценозе отмечено 4 вида растений, внесенных в список охраняемых в регионе [4], сведения о которых приведены ниже.

Характеристика мозаики размещения особей отмеченных видов. Кроме четырех редких видов (Artemisia salsoloides, Hedysarum grandiflorum Oxytropis floribunda и Stipa korshinskyi) на исследуемой территории отмечались еще два представителя, нуждающихся в региональной охране Ephedra distachya L. и Onosma simplicissima L. Плотность растений на исследуемой площадке варьировала в пределах 3-5 экз./ ${ }^{2}$, увеличение плотности отмечалось от периферии к центру, общее число особей составило 104 экз. (рис. 1А).

С помощью критерия согласия Пирсона выявлен нестационарный характер размещения особей всех видов $\left(\chi^{2}=21,33 ; \mathrm{p}=0,0006\right)$. Проверка, выполненная по критерию Колмогорова-Смирнова, показала отсутствие тренда интенсивности расположения всех растений на площадке как вдоль оси $\mathrm{X}$, так и вдоль оси $\mathrm{Y}\left(\mathrm{p}_{\mathrm{x}}=0,92 ; \mathrm{p}_{\mathrm{y}}=0,45\right)$.

Результат графической интерпретации функции Рипли показал наличие небольшого разрежения в расположении особей на расстояние 0,4 м (рис. 1В). Такое распределение особей характерно для окраины площадки, и может быть обусловлено уничтожением части растений в связи с выпасом скота.

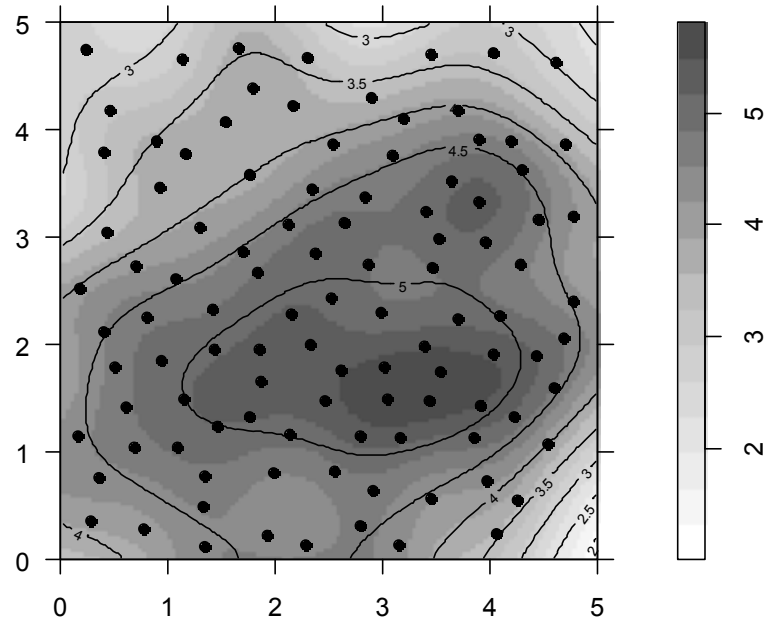

A

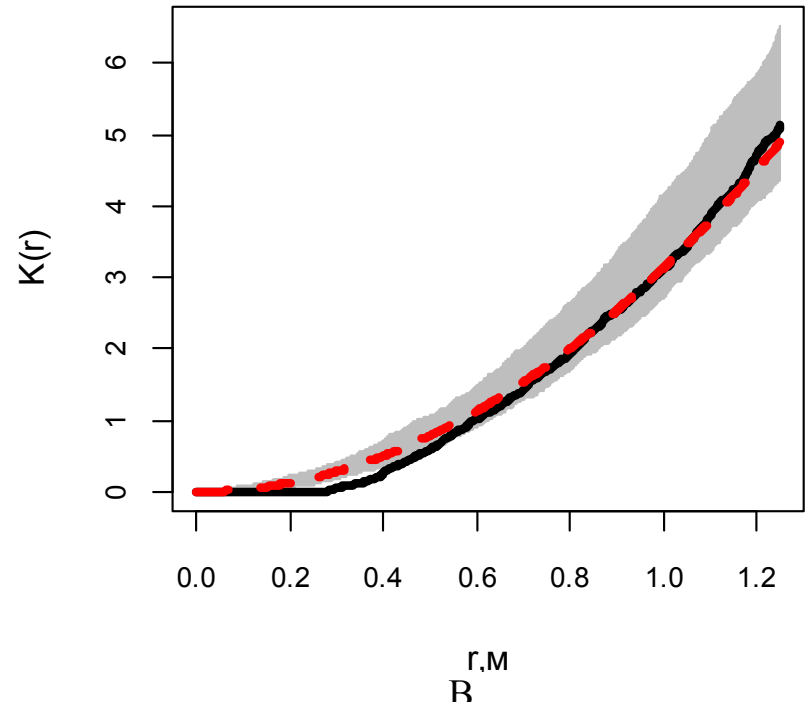

B

Рис. 1. Пространственная структура размещения исследуемых видов

А: Карта-схема локальной плотности (темные участки соответствуют более высокой плотности особей). В: Поведение функции Рипли 
Состояние ценопопуляций некоторых редких видов растений Самарской области...

Для анализа межвидовых отношений растений, обитающих в границах исследуемой территории, рассчитывались кросс-функции Рипли, позволяющие выявить наличие группирования или отталкивания одних видов относительно других. Результаты показали, что все виды располагаются случайным образом по отношению друг к другу, за исключением пары: Hedysarum grandiflorum и Stipa korshinskyi. Визуально расположение особей двух видов выглядит хаотично (рис. 2А). При выполнении расчетов отмечается наличие отталкивания особей S.korshinskyi от H. grandiflorum на расстояние около 0,7-0,9 м (рис. 2В). Большая часть ковыля располагалась на участках, свободных от копеечника, только несколько $\mathrm{g}_{2}$ особей S.korshinskyi «пересекались» с генеративными особями H. grandiflorum, что, возможно, привело к слабому отталкиванию в рамках конкуренции за пространство.
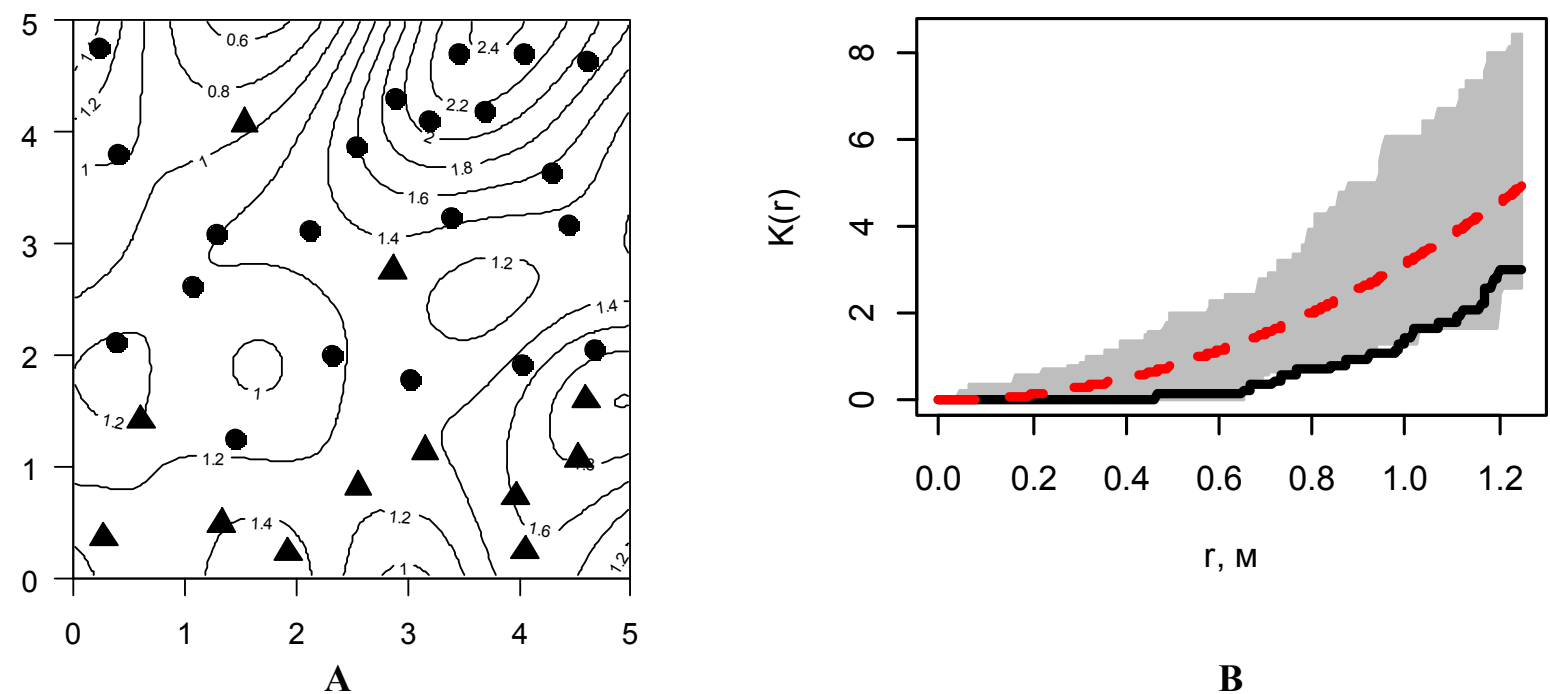

Рис. 2. Пространственная структура размещения Hedysarum grandiflorum и Stipa korshinskyi

А: Карта-схема локальной плотности: - Hedysarum grandiflorum и $\boldsymbol{\Delta}$-Stipa korshinskyi.

B: Поведение кросс-функции Рипли при взаимном размещении Hedysarum grandiflorum и Stipa korshinskyi

Анализ пространственного узора редких видов. В сообществе наряду с ковылем преобладающими видами являются Artemisia salsoloides (22 экз.), Hedysarum grandiflorum (21 экз.) и Oxytropis floribunda (20 экз.).

Виды содоминанты в пределах исследуемой территории характеризуются невысокой плотностью особей, так плотность полыни варьировала в пределах $0,5-1,6$ экз./ $\mathbf{M}^{2}$, копеечника $0,6-2,4$ экз./ $\mathrm{M}^{2}$ и особей остролодочника $0,6-2$ экз./м² (рис. $3 \mathrm{~A}$, рис. $4 \mathrm{~A}$, рис. $5 \mathrm{~A}$ ).

С помощью критерия согласия Пирсона выявлен стационарный характер размещения особей полыни $\left(\chi^{2}=3,36 ; \mathrm{p}=0,18\right)$. Расчеты D-статистики показали отсутствие тренда интенсивности расположения особей полыни как вдоль оси $\mathrm{X}$, так и вдоль оси $\mathrm{Y}\left(\mathrm{p}_{\mathrm{x}}=0,73 ; \mathrm{p}_{\mathrm{y}}=0,47\right)$ (рис. 3B).

Особи копеечника размещаются стационарно $\left(\chi^{2}=10,29 ; \mathrm{p}=0,49\right)$, но наблюдается тренд интенсивности по оси $\mathrm{Y}\left(\mathrm{p}_{\mathrm{x}}=0,68 ; \mathrm{p}_{\mathrm{y}}=0,03\right)$ (рис. 4B).

Особи остролодочника яркоцветного располагаются нестационарно $\left(\chi^{2}=20,5 ; \mathrm{p}=0,02\right)$, также отмечен тренд по оси $\mathrm{X}\left(\mathrm{p}_{\mathrm{x}}=0,02 ; \mathrm{p}_{\mathrm{y}}=0,91\right)$ (рис. 5B).

Численность ковыля на учетной площадке составляет всего 13 экземпляров (однако для всего сообщества является доминирующим видом), в связи с небольшим количеством объектов невозможно применить пространственную статистику [10]. Следовательно, для оценки характера размещения Stipa korshinskyi рассчитывался индекс Мористы [23], который варьировал в пределах 0,7-1,6, что говорит о тенденции к агрегированию растений. Ценопопуляция ковыля располагалась ниже модельной площадки и захватывала ее только небольшой частью, что, вероятно, и послужило причиной некоторого обособления особей S. korshinskyi.

Согласно полученным значениям $K(r)$ функции выявлено случайное размещение особей Artemisia salsoloides, Hedysarum grandiflorum, Oxytropis floribunda, а также сопутствующих видов (Ephedra distachya, Onosma simplicissima, Scabiosa isetensis, Euphorbia seguieriana, Echinops ritro и 
др.). Следовательно, внутривидовое взаимодействие (как положительное, так и отрицательное) между особями исследуемых видов отсутствует.

Некоторое смещение $H$. grandiflorum в северном направлении и смещение $O$. floribunda в восточном направлении в границах площадки может быть результатом воздействия водной и ветровой эрозии и особенностями микрорельефа.

В возрастном спектре полыни солянковидной отсутствуют проростки и ювенильные возрастные состояния, также полностью отсутствуют растения постгенеративного периода. Преобладающими являются $g_{2}$ и $v$ особи. У копеечника преобладают $i m, g_{2}$ особи, у остролодочника $v, g_{2}$ особи, у обоих видов также отсутствуют проростки и возрастные состояния сенильного периода.

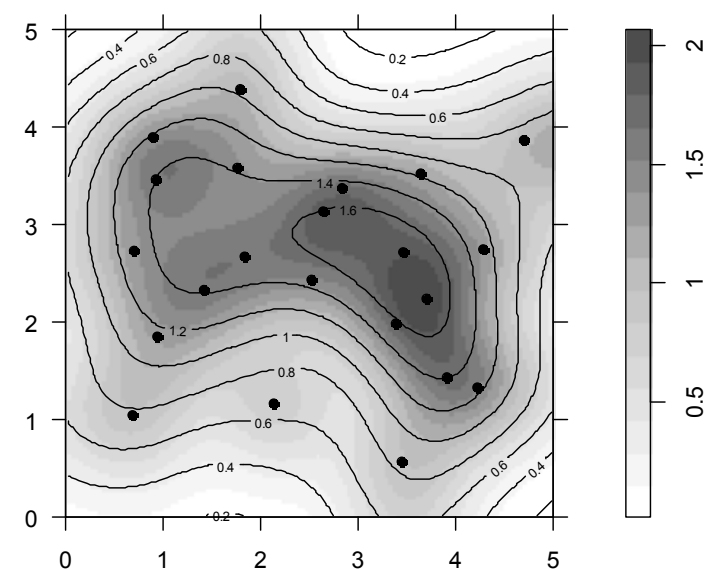

A

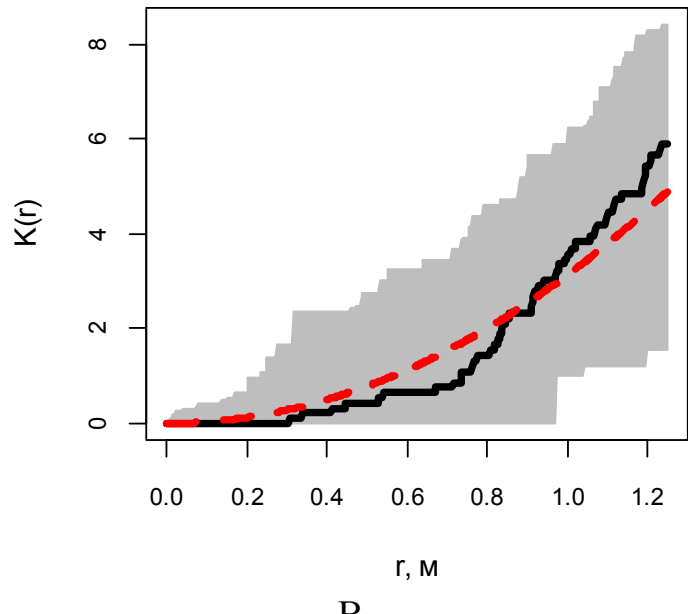

B

Рис. 3. Пространственная структура размещения Artemisia salsoloides

A: Карта-схема локальной плотности (темные участки соответствуют более высокой плотности особей). В: Поведение функции Рипли
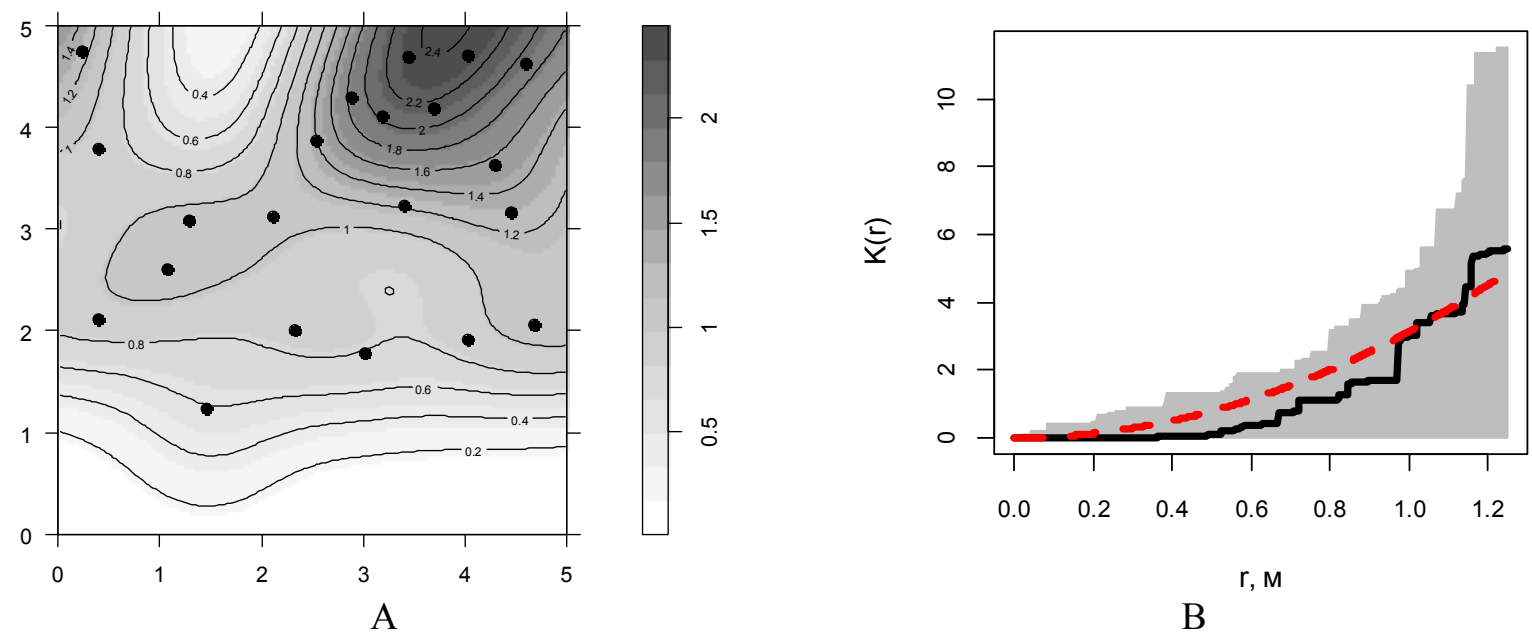

Рис. 4. Пространственная структура размещения Hedysarum grandiflorum

A: Карта-схема локальной плотности (темные участки соответствуют более высокой плотности особей). В: Поведение функции Рипли

Частые засухи могли привести к исчезновению проростков, но в целом, сообщество является устойчивым благодаря наличию большого количества прегенеративных и зрелых особей видов-эдификаторов. Случайное размещение особей доминирующих видов, свидетельствует об оптимальном и наиболее целесообразном их распределении по территории [32]. 
Состояние ценопопуляций некоторых редких видов растений Самарской области...

11 СЕРИЯ БИОЛОГИЯ. НАУКИ О ЗЕМЛЕ 2021. Т. 31, вып. 1
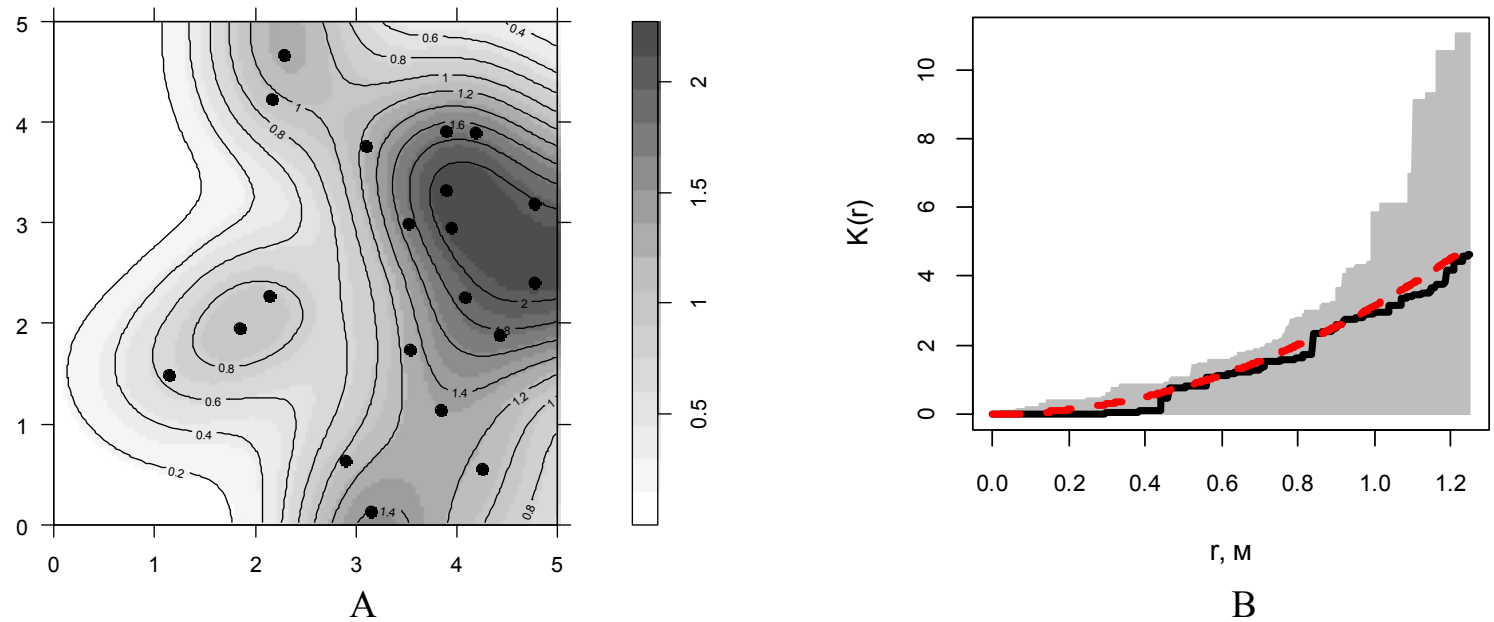

Рис. 5. Пространственная структура размещения Oxytropis floribunda

A: Карта-схема локальной плотности (темные участки соответствуют более высокой плотности особей) В: Поведение функции Рипли

Выявление закономерностей внутривидовых отношений редких растений. В ходе работ мы попытались выяснить, есть ли тренд размещения прегенеративных и генеративных особей $A$. salsoloides, H. grandiflorum и O. floribunda. Можно ли выделить территориальные границы между различными возрастными группами вышеуказанных видов? Особи Stipa korshinskyi находились только в средневозрастных генеративных состояниях $\left(g_{2}\right)$, поэтому в данном анализе не участвовали.

Карты распределения доминирующих возрастных состояний показали, что прегенеративные особи полыни солянковидной располагаются более интенсивно в северной части, а генеративные в южной части площадки (рис. 6А).

Взрослые растения копеечника крупноцветкового сконцентрированы в восточной и западной частях территории, молодые - в южной и северной частях (рис. 6В).

Основная часть взрослых особей остролодочника яркоцветкового размещена по диагонали в северо-западном и юго-восточном направлении. Прегенеративные особи концентрируются по обе стороны от вышеуказанной диагонали в северо-восточной и юго-западной частях (рис. 6С).

Рассчитанные кросс-функции Рипли показали, что генеративные и прегенеративные особи располагаются случайно по отношению друг к другу.
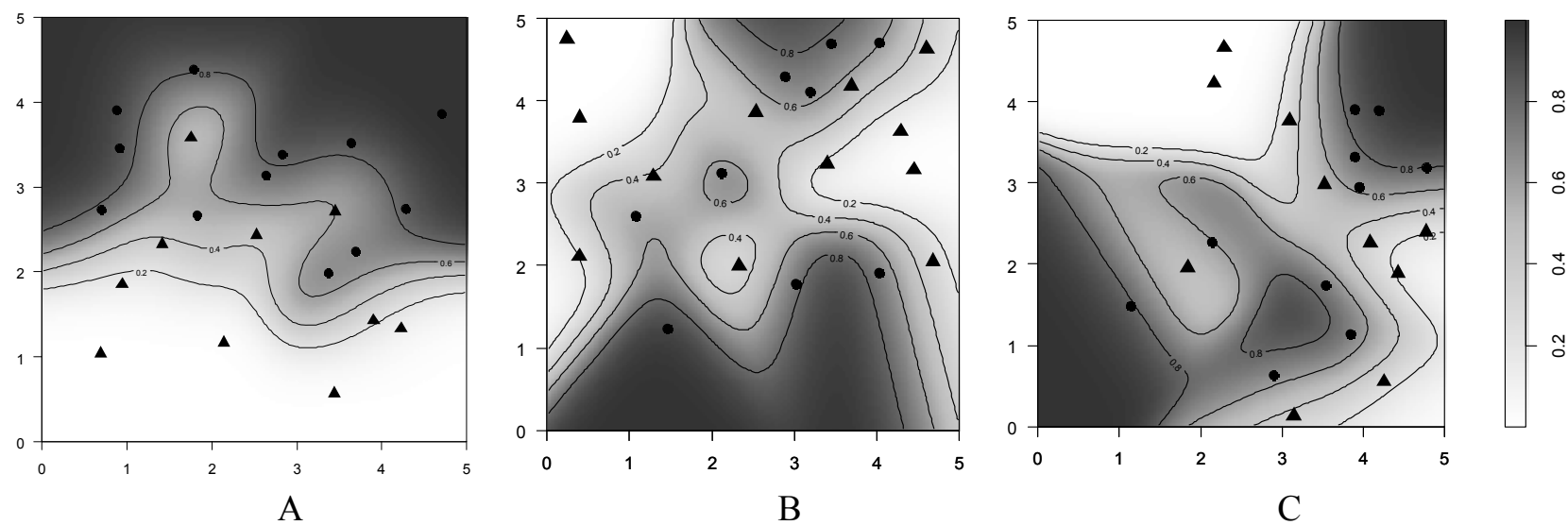

Рис. 6. Карты распределения возрастных состояний А: Artemisia salsoloides, В: Hedysarum grandiflorum, C: Oxytropis floribunda; черные точки - прегенеративные возрастные состояния; черные треугольники - генеративные возрастные состояния; более темные участки соответствуют местам наиболее вероятной встречи прегенеративных особей

Таким образом, выявлено, что исследуемая территория имеет выраженное распределение между возрастными группами особей видов доминантов, при этом внутривидовая конкуренция отсутствует, растения не отталкиваются друг от друга. 


\section{Заключение}

На территории памятника природы регионального значения «Серноводный шихан» (Сергиевский район, Самарская область) в составе ковыльно-разнотравного сообщества выявленный тип пространственной структуры ЦП всех присутствующих видов характеризуется случайным размещением особей, в том числе у доминантов и содоминантов (Stipa korshinskyi, Artemisia salsoloides, Hedysarum grandiflorum и Oxytropis floribunda). Отмеченное в ходе работ небольшое отталкивание особей говорит о наличии слабой межвидовой конкуренции отдельных видов, не влияющей на общий рисунок их ценопопуляций. Преобладающие на данном участке виды эффективно распределили между собой пространство таким образом, чтобы всем хватало ресурсов и реализовывалась возможность роста и размножения. Это свидетельствует об устойчивости фитоценоза в условиях умеренной антропогенной нагрузки.

Изучаемый фитоценоз находится в сложных природных условиях, характеризующихся засухой, водной и ветровой эрозией. Для того, чтобы не сдвинуть существующее равновесие в растительных сообществах в сторону их деградации, дополнительный пресс, связанный с выпасом скота, рекреацией, строительной деятельностью и отчуждением земель, должен находиться под строгим контролем.

Проанализированный участок может быть использован в качестве фоновой площадки при выполнении экологического мониторинга на территории памятника природы регионального значения «Серноводный шихан».

\section{СПИСОК ЛИТЕРАТУРЫ}

1. Зеленая книга Самарской области: редкие и охраняемые растительные сообщества / под ред. Г.С. Розенберга, С.В. Саксонова. Самара: Самар. НЦ РАН, 2006. 201 с.

2. Реестр особо охраняемых природных территорий регионального значения Самарской области / сост. А.С. Паженков. Самара: «Экотон», 2010. 259 с.

3. Красная книга Самарской области. Т. 1. Редкие виды растений, лишайников, и грибов / под ред. Г.С. Розенберга, С.В. Саксонова. Тольятти: ИЭВБ РАН, 2007. 372 с.

4. Красная книга Самарской области. Т. І. Редкие виды растений и грибов, изд. 2-е, перераб. и доп. / под ред. С.А. Сенатора, С.В. Саксонова. Самара: Изд-во Самарской государственной областной академии (Наяновой), 2017. 384 с.

5. Абрамова Л.М., Ильина В.Н., Каримова О.А., Мустафина А.Н. Сравнительный анализ структуры популяций Hedysarum grandiflorum (Fabaceae) в Самарской области и Республике Башкортостан // Растительные ресурсы. 2016. Т. 52. № 2. С. 225-239.

6. Абрамова Л.М., Ильина В.Н., Мустафина А.Н., Каримова О.А. Особенности организации популяций редкого вида Cephalaria uralensis (Murr.) Schrad. ex Roem. et Schult (Dipsacaceae) в Заволжье и Предуралье // Поволжский экологический журнал. 2018. № 1. С. 3-15. DOI: 10.18500/1684-7318-2018-1-3-15.

7. Зенкина Т.Е., Ильина В.Н. Особенности структуры ценопопуляций полыни солянковидной (Artemisia salsoloides Willd., Asteraceae) в Самарской области // Самарский научный вестник. 2017. Т. 6, № 4 (21). С. 41-47.

8. Популяционная организация растительного покрова лесных территорий (на примере широколиственных лесов европейской части СССР) / О.В. Смирнова, А.А. Чистякова, Р.В. Попадюк, О.И. Евстигнеев, В.Н. Коротков, М. В. Митрофанова, Е.В. Пономаренко. Пущино: Изд-во АН СССР, 1990. 92 с.

9. Фардеева М.Б. Многолетняя динамика пространственно-временной структуры популяций Orchis militaris L. (Orchidaceae Juss.) // Изв. Самарского научного центра РАН. 2013. Т. 15. № 3(1). С. 352-357.

10. Фардеева М.Б., Исламова Г.Р., Чижикова Н.А. Анализ пространственно-возрастной структуры растений на основе информационно-статистических подходов // Уч. зап. Казанского гос. ун-та. Серия: Естественные науки. 2008. Т. 150. № 4. С. 226-240.

11. Фардеева М.Б., Исламова Г.Р. К изучению пространственной структуры черники (Vaccinium myrtillus L.) // Tp. Всеросс. конф. с межд. уч. «Окружающая среда и устойчивое развитие регионов: новые методы и технологии исследований» / ред. Э.В. Скворцов, Т.В. Рогова. Казань: «Бриг», 2009. С.307-312.

12. Математические подходы к анализу пространственно-возрастной структуры популяций дерновинных видов трав / М.Б. Фардеева, Н.А. Чижикова, Н.В. Бирючевская, Т.В. Рогова, А.А. Савельев // Экология. 2009. № 4. C. 249-257.

13. Красная книга Российской Федерации (Растения и грибы) / Гл. ред-колл.: Ю.П. Трутнев и др.; Сост. Р.В. Камелин и др. М.: Товарищество научных изданий КМК, 2008. 855 с.

14. Работнов Т.А. Жизненный цикл многолетних травянистых растений в луговых ценозах. Труды БИН АН СССР // Серия 3. Геоботаника. М.-Л., 1950. Вып.6. С. 77-204.

15. Уранов А.А. Возрастной спектр фитоценопопуляций как функция времени и энергетических волновых процессов // Биологические науки. 1975. № 2. С. 7-34.

16. Жукова Л.А. Популяционная жизнь луговых растений. Йошкар-Ола: РИИК «Ланар», 1995. 224 с. 
Состояние ценопопуляций некоторых редких видов растений Самарской области...

17. Фардеева М.Б., Рогова Т.В. Методы изучения пространственно-возрастной структуры популяций растений // Растительные ресурсы. 2012. Т. 48, вып. 4. С. 597-613.

18. Фардеева М.Б., Исламова Г.Р., Мухаметгалиева Л.Я. Особенности пространственной популяционной структуры хохлатки луковичной (Corydalis bulbosa (L.) DC) в зоне хвойно-широколиственных лесов // Принципы и способы сохранения биоразнообразия (Матер. III Всерос. науч. конф.) / ред. Л.А. Жукова. Йошкар-Ола, Пущино: Мар. гос. ун-т, 2008. С. 380-382.

19. Фардеева М.Б., Чижикова Н.А., Красильникова О.В. Многолетняя динамика онтогенетической и пространственной структуры ценопопуляций Cypripedium calceolus L. // Уч. зап. Казанского гос. ун-та. Серия: Естественные науки. 2010. Т. 152, №. 3. С. 159-173.

20. Фардеева М.Б., Исламова Г.Р., Чижикова Н.А. Пространственно-онтогенетическая структура ценопопуляций Vaccinium myrtillus (Ericaceae) близ южной границы ареала (Республика Татарстан) // Растительные ресурсы. 2014. Т. 50. Вып. 3. С. 376-397.

21. Грабарник П.Я., Алейников А.А., Ефименко А.С. Анализ пространственной структуры разновозрастных древостоев методами случайных точечных полей // Материалы Четвертой Национальной научной конференции с международным участием «Математическое моделирование в экологии» / ред. А.С. Комаров. Пущино: ИФХиБПП РАН, 2015. С. 58-59.

22. Секретенко О.П., Грабарник П.Я. Анализ горизонтальной структуры древостоев методами случайных точечных полей // Сибирский лесной журнал. 2015. №3. С. 32-44.

23. Савельев А.А., Мухарамова С.С., Чижикова Н.А., Пилюгин А.Г. Теория пространственных точечных процессов в задачах экологии и природопользования (с применением пакета R). Казань: Изд-во Казан. ун-та, 2014. $146 \mathrm{c}$

24. Bailey T.C., Gatrell A.C. Interactive spatial data analysis. Harlow, England: Longman Group, 1995. 413 p.

25. Silverman B.W. Density estimation for statistics and data analysis. London: Chapman and Hall, 1986. $175 \mathrm{p}$.

26. Scott D.W. Multivariate density estimation. Theory, Practice and Visualization. New-York: John Wiley \& Sons Ltd., $1992.317 \mathrm{p}$.

27. Шитиков В.К., Розенберг Г.С. Рандомизация и бутстреп: статистический анализ данных по биологии и экологии с использованием R. Тольятти: Кассандра, 2014. 314 с.

28. Ripley B.D. The second-order analysis of stationary point processes // Journal of Applied Probability. 1976. Vol. 13. P. 255-266.

29. Besag J., Diggle P.J. Simple Monte Carlo tests for spatial pattern // Applied Statistics. 1977. Vol. 26. P. 327-233.

30. Мастицкий С.Э., Шитиков В.К. Статистический анализ и визуализация данных с помощью R. Хайдельберг. Лондон - Тольятти, 2014. 401 с. (электронная книга). URL: http://r-analytics.blogspot.com. (дата обращения: 24.05.2019).

31. Baddeley A. and Turner R. Spatstat: an R packadge for analysing spatial point patterns // Journal of Statistical Software. 2005. 12 (6): 1-42. URL: www.jstatsoft.org, ISSN: 1548-7660. (дата обращения: 24.03.2019).

32. Миркин Б.М., Розенберг Г.С. Фитоценология. Принципы и методы. М.: Наука, 1978. 212 с.

Поступила в редакцию 04.02.2021

Зенкина Татьяна Евгеньевна, кандидат биологических наук, доцент кафедры биологии

ФГБОУ ВО «Волгоградский государственный университет»

400062, Россия, г. Волгоград, просп. Университетский, 100

начальник отдела экологии,

ООО «Волгограднефтепроект»

400048, Россия, г. Волгоград, ул. Лесогорская, д.85а

E-mail: tatyanaez@mail.ru

Ильина Валентина Николаевна, кандидат биологических наук, доцент, доцент

ФГБОУ ВО «Самарский государственный социально-педагогический университет»

426090, Россия, г. Самара, ул. Максима Горького, д. 65/67

E-mail: 5iva@mail.ru

T.E. Zenkina, V.N. Il'ina

STATE OF CENOPOPULATIONS OF SOME RARE SPECIES OF PLANTS OF SAMARA REGION IN THE TERRITORY OF NATURE MONUMENT OF REGIONAL IMPORTANCE "SERNOVODNY SHIKHAN"

DOI: $10.35634 / 2412-9518-2021-31-1-5-15$

The condition of cenopopulations of four rare species (Artemisia salsoloides, Hedysarum grandiflorum, Oxytropis floribunda, Stipa korshinskyi) in the petrophytic steppes of the High Zavolzh'ye (High Transvolga, Samara region) was stud- 
ied on the basis of the regularities of their spatial and ontogenetic structure. The data were processed using the software package $\mathrm{R}$, which allows us to perform calculations of spatial statistics. Thus, stationarity, isotropy, and intensity of plant objects location were evaluated. The mosaic distribution of individuals of all species recorded within the boundaries of the study area was characterized. Using local density maps, the sparseness of individuals on the outskirts of the model site, caused by cattle grazing, was revealed. The behavior of the Ripley's function showed an independent distribution of species as a consequence of weak interspecies competition. The spatial pattern and age spectrum of the studied rare protected dominant species were analyzed. The absence of seedlings and senile plants due to exposure to unfavorable factors of exogenous nature was noted. The im-v and $\mathrm{g}_{2}$ states were the most numerous. In accordance with the behavior of the $\mathrm{K}(\mathrm{r})$ function, the random placement of the four predominant species was revealed, indicating their optimal location within the study area. Patterns of mutual placement of pregenerative and generative individuals of Artemisia salsoloides, Hedysarum grandiflorum, and Oxytropis floribunda were studied. Calculation of the Ripley's crossfunction showed that individuals of different age groups of the described species are located independently from each other, demonstrating the absence of intraspecific competition. Undoubtedly, the spatial distribution of individuals of the plant species composing the phytocenosis is influenced both by grazing and by the features of the soil cover of the site, which is manifested by significant elimination of plants at the initial stages of ontogenesis. Nevertheless, the cenopopulations of rare species are stable, mature and promising, and the individuals are distributed in an optimal way that minimizes energy costs.

Keywords: rare species, Artemisia salsoloides, Hedysarum grandiflorum, Oxytropis floribunda, Stipa korshinskyi, cenopopulation, spatial structure, Ripley's function, Samara region, Sernovodny shikhan.

\section{REFERENCES}

1. Zelenaya kniga Samarskoy oblasti: redkie i okhranyaemye rastitel'nye soobshchestva [Green Book of the Samara Region: rare and protected plant communities], G.S. Rozenberg and S.V. Saksonov (ed.), Samara: Samar. NTS RAN, 2006, 201 p. (in Russ.).

2. Reestr osobo okhranyaemykh prirodnykh territoriy regional'nogo znacheniya Samarskoy oblasti [Register of specially protected natural areas of regional significance of the Samara region], A.S. Pazhenkov (ed), Samara: Ekoton Publ., 2010, 259 p. (in Russ.).

3. Krasnaya kniga Samarskoy oblasti. T. 1. Redkie vidy rasteniy, lishaynikov, i gribov [Red Book of the Samara region. vol. 1. Rare species of plants, lichens and fungi], G.S. Rozenberg and S.V. Saksonov, Togliatti: IEVB RAN, 2007, 372 p. (in Russ.).

4. Krasnaya kniga Samarskoy oblasti. Tom I. Redkie vidy rasteniy i gribov [Red Book of the Samara region. Volume I. Rare species of plants and fungi], 2nd ed., S. A Senator and S. V. Saksonov, Samara: Samar. Gos. Oblast. Akad. Publ., (Nayanovoy) Publ., 2017, 384 p. (in Russ.).

5. Abramova L.M., Il'ina V.N., Karimova O.A., Mustafina A.N. [Comparative analysis of population structure of Hedysarum grandiflorum (Fabaceae) in Samara region and Bashkortostan Republic], in Rastitel'nye resursy, 2016, vol. 52, no. 2, pp. 225-239 (in Russ.).

6. Abramova L.M., Il'ina V.N., Mustafina A.N., Karimova O.A. [Features of the population organization of the rare species Cephalaria uralensis (Murr.) Schrad. ex Roem. et Schult (Dipsacaceae, Magnoliopsida) in the Trans-Volga and Cis-Urals regions], in Povolzhskiy ekologicheskiy zhurnal, 2018, no. 1, pp. 3-15. DOI: 10.18500/1684-73182018-1-3-15. (in Russ.).

7. Zenkina T.Ye., Ilina V.N. [Structure features of Artemisia salsoloides Willd. (Asteraceae) coenotic populations in the Samara region], in Samarskiy nauchnyy vestnik, 2017, vol. 6, no. 4 (21), pp. 41-47 (in Russ.).

8. Smirnova O.V., Chistyakova A.A., Popadyuk R.V., Evstigneev O.I., Korotkov V.N., Mitrofanova M.V., Ponomarenko E.V. Populyatsionnaya organizatsiya rastitel'nogo pokrova lesnykh territoriy (na primere shirokolistvennykh lesov evropeyskoy chasti SSSR) [Population organization of the vegetation cover of forest areas (on the example of deciduous forests of the European part of the USSR)], Pushchino: AN SSSR Publ., 1990,92 p. (in Russ.).

9. Fardeeva M.B. [Long-term dynamics of spatial and temporal population structure of Orchis militaris L. (Orchidaceae Juss.)], in Izvestiya Samarskogo nauchnogo tsentra RAN, 2013, vol. 15, no. 3(1), pp. 352-357 (in Russ.).

10. Fardeeva M.B., Islamova G.R., Chizhikova N.A. [Analysis of the spatial-age structure of plants on the basis of information-statistical approaches], in Uchenye zapiski Kazanskogo Gos. Univ. Ser.: Estestvennye nauki, 2008 , vol. 150, no. 4, pp. 226-240 (in Russ.).

11. Fardeeva M.B., Islamova G.R. [To the study of the spatial structure of blueberries (Vaccinium myrtillus L.)], in Trudy Vseros. konf. s mezhd. uch. "Okruzhayushchaya sreda i ustoychivoe razvitie regionov: novye metody $i$ tekhnologii issledovaniy», E.V. Skvortsov and T.V. Rogova (ed), Kazan': Brig Publ., 2009, pp. 307-312 (in Russ.).

12. Fardeeva M.B., Chizhikova N.A., Biryuchevskaya N.V., Rogova T.V., Savel'ev A.A. [Mathematical approaches to the analysis of the spatial-age structures of tussock herb species], in Ekologiya [Russian Journal of Ecology], 2009, no. 4, pp. 249-257 (in Russ.). 
Состояние ценопопуляций некоторых редких видов растений Самарской области...

13. Krasnaya kniga Rossiyskoy Federatsii (Rasteniya i griby) [Red Book of the Russian Federation (Plants and Fungi)], Kamelin R.V. et al (ed), Moscow: Tovarishchestvo nauchnykh izdaniy KMK Publ., 2008, 855 p. (in Russ.).

14. Rabotnov T.A. [Life cycle of perennial herbaceous plants in meadow cenoses], in Trudy BIN AN SSSR, Ser. 3, Geobotanika, Moscow-Leningrad, 1950, iss. 6, pp. 77-204 (in Russ.).

15. Uranov A.A. [Age spectrum of phytocenopopulations as a function of time and energy wave processes], in Biologicheskiye nauki, 1975, no. 2, pp. 7-34 (in Russ.).

16. Zhukova L.A. Populyatsionnaya zhizn' lugovykh rasteniy [Population life of meadow plants], Yoshkar-Ola: RIIK "Lanar" Publ., 1995, 224 p. (in Russ.).

17. Fardeeva M.B., Rogova T.V. [Methods of investigation in spatial and age structure of plant population], in Rastitel'nye resursy, 2012, vol. 48, iss. 4, pp. 597-613 (in Russ.).

18. Fardeeva M.B., Islamova G.R., Mukhametgaliyeva L.Ya. [Features of the spatial population structure of the bulbous corydalis (Corydalis bulbosa (L.) DC) in the zone of coniferous-broad-leaved forests], in Mater. III Vseros. nauch. konf "Printsipy i sposoby sokhraneniya bioraznoobraziya", L.A. Zhukova (ed), Yoshkar-Ola, Pushchino: Mariyskiy Gos. Univ., 2008, pp. 380-382 (in Russ.).

19. Fardeeva M.B., Chizhikova N.A., Krasil'nikova O.V. [Long-term dynamics of ontogenetic and spatial structure of coenopopulations of Cypripedium calceolus L.], in Uchenye zapiski Kazanskogo gos. un-ta. Seriya: Estestvennye nauki, 2010, vol. 152, no. 3, pp. 159-173 (in Russ.).

20. Fardeeva M.B., Islamova G.R., Chizhikova N.A. [Spatial and ontogenetic structure of coenopopulations of Vaccinium myrtillus (Ericaceae) on the southern border of the area (Tatarstan Republic)], in Rastitel'nye resursy, 2014, vol. 50, iss. 3, pp. 376-397 (in Russ.).

21. Grabarnik P.Ya., Aleynikov A.A., Yefimenko A.S. [Analysis of the spatial structure of forest stands of different ages by the methods of random point fields], in Mater. Chetvertoy Nats. Nauch. konf. s mezhd. uch. "Matematicheskoye modelirovanive v ekologii”, Komarov A.S. (ed), Pushchino: IFKhiBPP RAN, 2015, pp. 58-59 (in Russ.).

22. Sekretenko O.P., Grabarnik P.Ya. [Analysis of tree stand horizontal structure using random point field methods], in Sibirskiy lesnoy zhurnal, 2015, no. 3, pp. 32-44 (in Russ.).

23. Savel'yev A.A., Mukharamova S.S., Chizhikova N.A., Pilyugin A.G. Teoriya prostranstvennykh tochechnykh protsessov $v$ zadachakh ekologii i prirodopol'zovaniya (s primeneniem paketa $R$ ) [The theory of spatial point processes in problems of ecology and nature management (using the R package)], Kazan': Kazan. Univ., 2014, 146 p. (in Russ.).

24. Bailey T.C. and Gatrell A.C. Interactive spatial data analysis, Harlow, England: Longman Group, 1995, 413 p.

25. Silverman B.W. Density estimation for statistics and data analysis, London: Chapman and Hall, 1986, $175 \mathrm{p}$.

26. Scott D.W. Multivariate density estimation. Theory, Practice and Visualization, New-York: John Wiley \& Sons Ltd., 1992, $317 \mathrm{p}$.

27. Shitikov V.K., Rozenberg G.S. Randomizatsiya i butstrep: statisticheskiy analiz dannykh po biologii i ekologii s ispol'zovaniem $R$ [Randomization and bootstrap: statistical analysis of data on biology and ecology using R.], Tol'yatti: Kassandra Publ., 2014, 314 p. (in Russ.).

28. Ripley B. D. The second-order analysis of stationary point processes, in Journal of Applied Probability, 1976, vol. 13, pp. 255-266.

29. Besag J., Diggle P.J. Simple Monte Carlo tests for spatial pattern, Applied Statistics, 1977, vol. 26, pp. 327-233.

30. Mastitskiy S.E., Shitikov V.K. Statisticheskiy analiz $i$ vizualizatsiya dannykh $s$ pomoshch'yu $R$ [Statistical analysis and data visualization using R], Khaydel'berg - London - Tol'yatti, 2014. 401 p. Available at: http://ranalytics.blogspot.com. (accessed: 24.05.2019) (in Russ.).

31. Baddeley A. and Turner R. Spatstat: an R packadge for analysing spatial point patterns, in Journal of Statistical Software, 2005, vol. 12, no. 6, pp. 1-42. Available at: www.jstatsoft.org. (accessed: 24.03.2019)

32. Mirkin B.M., Rozenberg G.S. Fitotsenologiya. Printsipy i metody [Phytocenology. Principles and Methods], Moscow: Nauka Publ., 1978, 212 p. (in Russ.).

Received 04.02.2021

Zenkina T.E., Candidate of Biology, Associate professor, Associate professor at Department of Biology Volgograd State University

Prospekt Universitetskiy, 100, Volgograd, Russia, 400062

Head of the ecology department Volgogradnefteproyekt

Lesogorskaya st., 85a, Volgograd, Russia, 400048

E-mail: tatyanaez@mail.ru

Ilina V.N., Candidate of Biology, Associate professor, Associate professor at Department of Biology

Samara State University of Social Sciences and Education

Maxima Gor'kogo st., 65/67, Samara, Russia, 443099

E-mail: 5iva@mail.ru 